\title{
Karakteristik Morfometrik, Pola Sebaran, Kepadatan dan Kondisi Lingkungan Siput Gongong Strombus canarium Linnaeus, 1758 Di Perairan Kota Batam
}

\section{Morphometric Characteristics, Distribution Patterns, Density and Environmental Conditions of Dog Conch Strombus canarium in the Waters of Batam City}

\author{
Ramses $^{1}$, Fauziah Syamsi ${ }^{2 *}$ Notowinarto ${ }^{3}$ \\ ${ }^{123}$ Program Studi Pendidikan Biologi Universitas Riau Kepulauan, Indonesia \\ *Koresponden: fauziahsyamsi@gmail.com
}

\begin{abstract}
Abstak
Ekologi Siput Gonggong (Strombus canarium Linnaeus, 1758) masih kurang dipahami dan faktor-faktor yang mempengaruhi preferensi habitat tetap biota ini sebagian besar tidak dapat dijelaskan. Biota ini sangat digemari masyarakat sebagai menu utama kuliner seafood sehinga menyebabkan tingginya penangkapan di alam. Penelitian ini bertujun untuk menganalisis aspek morfometrik, populasi (tingkat kepadatan dan pola sebaran), faktor-faktor lingkungan (kualitas air, substrat, habitat lamun) biota Siput Gonggong. Pengambilan sampel dilakukan di tiga lokasi (stasiun) yang menjadi pusat penangkapan Siput Gonggong yang ada di Pulau Jaloh, Teluk Kangkung dan Pulau Terong, Kota Batam. Pengambilan sampel dalam penelitian ini mengikuti metode transek garis yang ditempatkan secara acak pada 3 titik pengamatan di setiap stasiun. Luas daerah pengamatan pada masing-masing stasium seluas $60 \mathrm{~m}^{2}$. Terdapat perbedaan morfometrik Siput Gonggong Strombus canarium pada tiga lokasi, dimana morfometrik di Pulau Jaloh memiliki ukuran lebih tinggi dari lokasi lainnya pada semua indikator ukuran. Sedangkan di Teluk Kangkung merupakan yang paling kecil untuk semua indikator ukuran. Kepadatan siput Gonggong di Pulau Jaloh sebesar 3.58 ind/ 60m², Teluk Kangkung $1.3 \mathrm{ind} / 60 \mathrm{~m}^{2}$, dan Pulau Terong sebesar $1.4 \mathrm{ind} / 60 \mathrm{~m}^{2}$ dengan pola sebaran pada semua lokasi mengelompok. Kualitas perairan di masing-masing lokasi pengamatan masih dalam rentang baku mutu kualitas air untuk biota. Dari ketiga lokasi penelitian ini yang dominan ditemukan jenis lamun Enhalus acoroides. Persentase tutupan lamun pada tiga lokasi yaitu Pulau Jaloh sebesar 6.5\%, Teluk Kangkung sebesar 8,3\%, dan Pulau Terong sebesar 14,98\% masih dalam kategori rendah.
\end{abstract}

Kata Kunci: Marfometrik, Pola Sebaran, Bioekologi, Gonggong Strombus canarium.

\begin{abstract}
Abstrac
The ecology of the Dog Conch (Strombus canarium, Linnaeus 1758) is still poorly understood and the factors that influence the habitat preference of this biota are largely inexplicable. This biota is very popular with the community as the main menu of seafood culinary, causing high fishing in the wild. This study aims to analyze morphometric aspects, population (density and distribution patterns), environmental factors (water quality, substrate, seagrass habitat), Dog Conch biota. Sampling was carried out in three locations (stations) which became the center of catching Dog Conch on Jaloh Island, Kangkung Bay, and Terong Island, Batam City. Sampling in this study followed a line transect method that was placed randomly at 3 observation points at each station. The area of observation in each station is $60 \mathrm{~m} 2$. There are morphometric differences in Dog Conch (Strombus canarium) at three locations, where morphometrics on Pulau Jaloh has a higher size than other locations on all size indicators. Whereas in Kangkung Bay is the smallest for all size indicators. The density of Dog Conch on Jaloh Island is 3.58 individu/60m2, Kangkung Bay is 1.3 individu/60 m2, and Pulau Terong is 1.4 individu/60 $\mathrm{m} 2$ with distribution patterns in all locations clustered. The water quality in each observation location is still within the range of water quality standards for biota. Of the three research locations, the dominant species of seagrass Enhalus acoroides were found. The percentage of seagrass cover in three locations namely Jaloh Island was 6.5\%, Kangkung Bay was $8.3 \%$, and Terong Island was $14.98 \%$, still in the low category.
\end{abstract}


Keywords: Morphometrics, Distribution Pattern, Bioecology, Dog Conch, Strombus canarium. PENDAHULUAN

Siput Gonggong Strombus canarium Linnaeus, 1758 merupakan biota yang menjadi kekhasan Kota Batam. Biota ini sangat digemari masyarakat sebagai menu utama kuliner seafood. Hal ini secara langsung menyebabkan tingginya pengambilan Siput Gonggong di alam unnuk tujuan komersil. Pulau Jaloh, Teluk Kangkung dan Pulau Terong dikenal sebagai daerah penghasil siput gonggong di Kota Batam. Masyarakat Kota Batam, khususnya Pulau Jaloh, Pulau Terong dan Teluk Kangkung mengenal siput Gonggong dengan sebutan gonggong betina, atau gonggong lumpur.

Ekologi Strombus canarium masih kurang dipahami dan faktor-faktor yang mempengaruhi preferensi habitat tetap biota ini sebagian besar tidak dapat dijelaskan, hal ini disebabkan masih minimnya penelitian terhadap spesies ini. Daerah dengan padang lamun Enhalus acoroides padat, meskipun dalam banyak laporan telah dikaitkan dengan spesies, yang mengejutkan para mikrohabitat paling tidak disukai. Hal ini disimpulkan bahwa preferensi terhadap mikrohabitat tertentu dalam padang lamun berhubungan dengan makan, dan interaksi intra-spesifik di antara individu (Cob et al., 2012). Status keberlanjutan populasi siput gonggong pada dimensi ekologi dapat di lihat dari empat varibel yang di ukur yaitu kondisi perairan, substrat, teknologi penangkapan dan ukuran penangkapan (Khodijah \& Anggraini 2015). Habitat Gonggong merupakan hamparan tumbuhan lamun jenis Thalassia hemprichii. Keberadaan lamun di habitat siput gonggong cukup penting karena menyangkut ketersediaan pasokan makanan yang berasal dari hancuran daun lamun (serasah) maupun sebagai tempat berlindung bagi anakan siput gonggong (Dody, 2011). Pada laporan lainnya, Cob et al., (2008) melaporkan parameter morfometri dari Strombus canarium Linnaeus, 1758 meliputi panjang tempel, panjang lingkran tubuh, lebar shell, kedalaman shell, ketebalan bibir shell, panjang aperture, bobot hewan dan berat batuan.

Untuk penyusunan rencana pelestarian (konservasi) dan pengembangan budidaya Siput Gonggong di masa depan, maka penting untuk mengetahui kondisi bioekologi Siput Gonggong. Sementara penelitian terkait biologi dan aspek ekologi Siput Gonggong secara komprehensif dan terencana di perairan Batam belum pernah dilakukan. Keberhasilan pengembangan budidaya Siput Gonggong di masa depan akan mampu menjawab permasalahan tingginya permintaan siput Gonggong tanpa bergantung pada populasinya di alam serta dapat meningkatkan pendapatan masyarakat nelayan. Penelitian ini bertujun untuk menganalisis bioekologi Siput Gonggong dari aspek morfometrik, populasi (tingkat 
kepadatan dan pola sebaran), faktor-faktor lingkungan meliputi: kualitas air, substrat, habitat lamun di Pulau Jaloh, Teluk Kangkung dan Pulau Terong yang menjadi sentra penangkapan Siput Gonggong di Kota Batam.

\section{METODE PENELITIAN}

Pengukuran morfometrik siput Gonggong yang diukur yaitu Shell Length (SL), Body Whorl Length (BW), Shell Width (SW), Sheel Depth (SD), Outer Lip/Lip thickness (OL) dan Aperture length (AL) serta beratnya (W) (Gambar 2). Untuk ukuran berat dilakukan penimbangan berat basahnya. Untuk mengukur morfometrik Gonggong di gunakan jangka sorong dan timbangan digital.
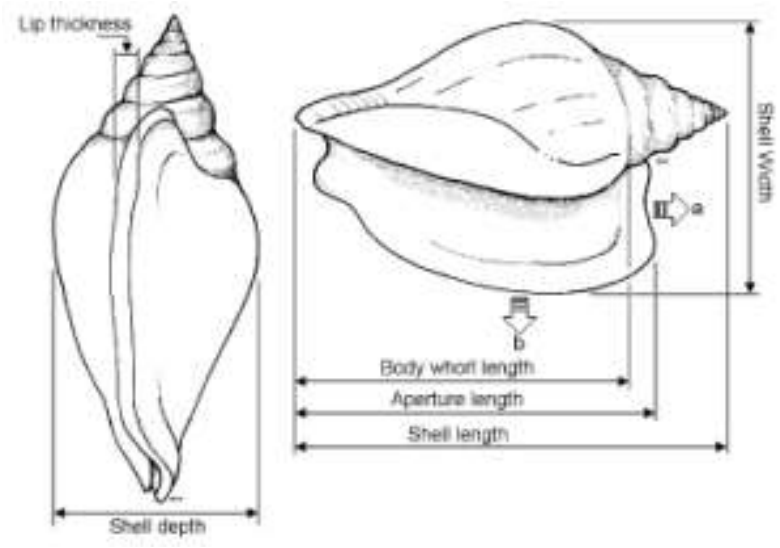

Gambar 1. Parameter pengukuran morfometrik Siput Gonggong

Pengukuran parameter kualitas perairan suhu $\left({ }^{\circ} \mathrm{C}\right)$, kecepatan arus (m/detik), pH, salinitas (ppm) dan DO (mg/l) diukur langsung di lokasi (insitu). Pengambilan contoh substrat dilakukan dengan menggunakan pipa paralon berdiameter $15 \mathrm{~cm}$ yang diletakkan di dasar perairan pada kedalaman $40 \mathrm{~cm}$, kemudian substrat di dasar diambil dengan menggunakan tangan dan diletakkan dalam kantong plastik. Penentuan tipe substrat ini menggunakan Segitiga Millar yang menggolongkan tipe substrat berdasarkan perbandingan liat, pasir, dan debu.

\section{Analisa Data}

\section{Kepadatan Gonggong}

Kepadatan jenis (a) gonggong dihitung berdasarkan jumlah individu per satuan luas. Kepadatan gonggong pada setiap stasiun dihitung dan dikonversikan dalam satuan individu/m² dengan menggunakan rumus (Brower et al., 1990 dalam Utami, 2012). 


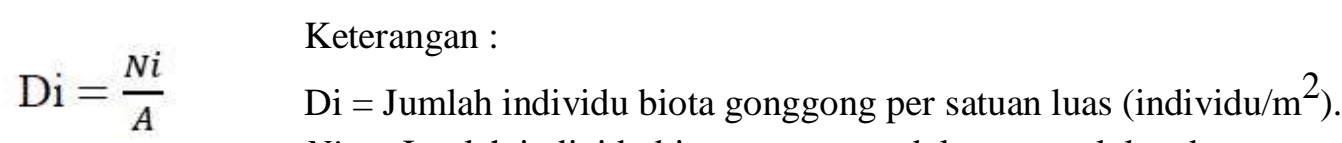

$$
\begin{aligned}
& N i=\text { Jumlah individu biota gonggong dalam transek kuadrat. } \\
& \mathrm{A}=\text { Luas transek kuadrat pengambilan contoh }\left(\text { meter }^{2}\right) \text {. }
\end{aligned}
$$

\section{Sebaran Gonggong}

Pola sebaran populasi siput gonggong ditentukan dengan menghitung indeks dispersi Morisita (I $\delta$ ) dengan persamaan (Brower et al., 1990 dalam Utami, 2012). Nilai indeks Morisita yang diperoleh diinterpretasikan sesuai dengan criteria berikut:

Id $<1$, distribusi individu bersifat seragam;

Id $=1$, distribusi individu cenderung acak;

Id $=>1$, distribusi individu cenderung berkelompok.

$$
\begin{aligned}
& I \delta=n \frac{\sum X_{i}^{2}-N}{N(N-1)} \quad \begin{array}{l}
\text { I } \delta=\text { Indeks dispesi morisita } \\
n=\text { Jumlah plot pengambilan contoh }
\end{array} \\
& N=\text { Jumlah individu dalam n plot } \\
& \sum X^{2}=\text { kuadrat jumlah individu gonggong pada setiap plot }
\end{aligned}
$$

Selanjutnya dilakukan uji chi kuadrat untuk menguji apakah suatu persebaran acak atau tidak, dengan rumus sebagai berikut :

$$
x^{2}=\left(n \sum X^{2} / N\right)-N \begin{aligned}
& \text { Keterangan: } \\
& \mathrm{x} 2=\text { Chi-Kuadrat } \\
& \mathrm{n}=\text { Jumlah pengamatan } \\
& \mathrm{X}^{2}=\text { Jumlah kuadrat gonggong yang ditemukan pada tiap stasiun } \\
& \mathrm{N}=\text { Jumlah seluruh Individu }
\end{aligned}
$$

Kemudian dilakukan perbandingan nilai $\mathrm{x}^{2}$-hitung dibandingkan dengan $\mathrm{x}^{2}$-tabel, dimana nilai $x^{2}$-hitung $>x^{2}$-tabel statistic dengan tingkat kepercayaan $95 \%(\alpha=0.05)$ dinyatakan sebagai penyebaran gonggong tidak acak, dan sebaliknya $\mathrm{x}^{2}$-hitung $<\mathrm{x}^{2}$-tabel, maka tidak berbeda nyata berarti penyebaran gonggong acak.

\section{Kondisi Habitat Lamun}

Untuk mengetahui kondisi habitat lamun dilokasi penelitian, dilakukan perhitungan terhadap komposisi jenis, frekwensi jenis dan frekwensi relatif, kerapatan jenis dan kerapatan relatif, penutupan jenis dan relative. Analisa tutupan lamun dihitung berdasarkan (English et al., 1997), dengan formula berikut:

$$
C=\frac{\sum(M i x f i)}{\sum f}
$$




\section{HASIL DAN PEMBAHASAN}

\section{Morfometrik Siput Gonggong}

Secara keseluruhan ukuran morfometrik Siput Gonggong di Pulau Lajoh lebih besar (panjang dan berat) dari lokasi lainnya. Nilai rata-rata ukuran morfometrik Gonggong di Pulau Jaloh adalah SL 64.29; AL 52.76; BW 50.20; SW 39.74; SD 29.83; OL2.54; SpH 20.27 dan W 27.64. Untuk lebih jelas dan rinci dapat dilihat pada Tabel 1 berikut:

Tabel 1. Morfometrik Siput Gonggong S.canarium Pulau Jaloh, Teluk Kangkung dan Pulau Terong

\begin{tabular}{ccccccc}
\hline \multirow{2}{*}{ Ukuran Tubuh } & \multicolumn{2}{c}{ Jaloh } & \multicolumn{2}{c}{ Teluk Kangkung } & \multicolumn{2}{c}{ Terong } \\
\cline { 2 - 7 } & Rerata & Selangkelas & Rerata & Selangkelas & Rerata & Selangkelas \\
\hline SL & 64.29 & $48.35-78,82$ & 51.34 & $14.40-62.90$ & 59.62 & $27.90-71.80$ \\
AL & 52.76 & $37.69-64.68$ & 40.27 & $22.00-50-80$ & 49.24 & $37.50-59.80$ \\
BW & 50.20 & $38.40-60-90$ & 37.26 & $24.00-47.50$ & 45.20 & $33.00-55.50$ \\
SW & 39.74 & $23.52-39.86$ & 30.32 & $17.95-39.50$ & 37.98 & $26.60-49.40$ \\
SD & 29.83 & $21.35-39.98$ & 23.98 & $15.00-35.00$ & 28.07 & $13.80-36.00$ \\
OL & 2.54 & $0.19-5.32$ & 1.95 & $0.05-6.95$ & 2.79 & $0.20-5.81$ \\
SpH & 20.27 & $13.73-28.08$ & 16.17 & $9.80-26.90$ & 17.46 & $11.00-23.26$ \\
W & 27.64 & $10.00-54.00$ & 13.91 & $3.00-23.00$ & 25.33 & $12.00-54.00$ \\
\hline
\end{tabular}

Keterangan : SL= Shell Length (Panjang Total); $\mathbf{A L}=$ Aperture Length (Panjang Bukaan Cangkang); BW = Body Whorl Length (Panjang Bibir); SW= Shell Width (Lebar Cangkang); SD= Shell Depth (Kedalaman Cangkang); OL= Outer Lip/Lip Tickness (Ketebalan Bibir Cangkang); $\mathbf{S p H = ~ T i n g g i ~}$ Spire; $\mathbf{W}=$ Weight (Berat Basah).
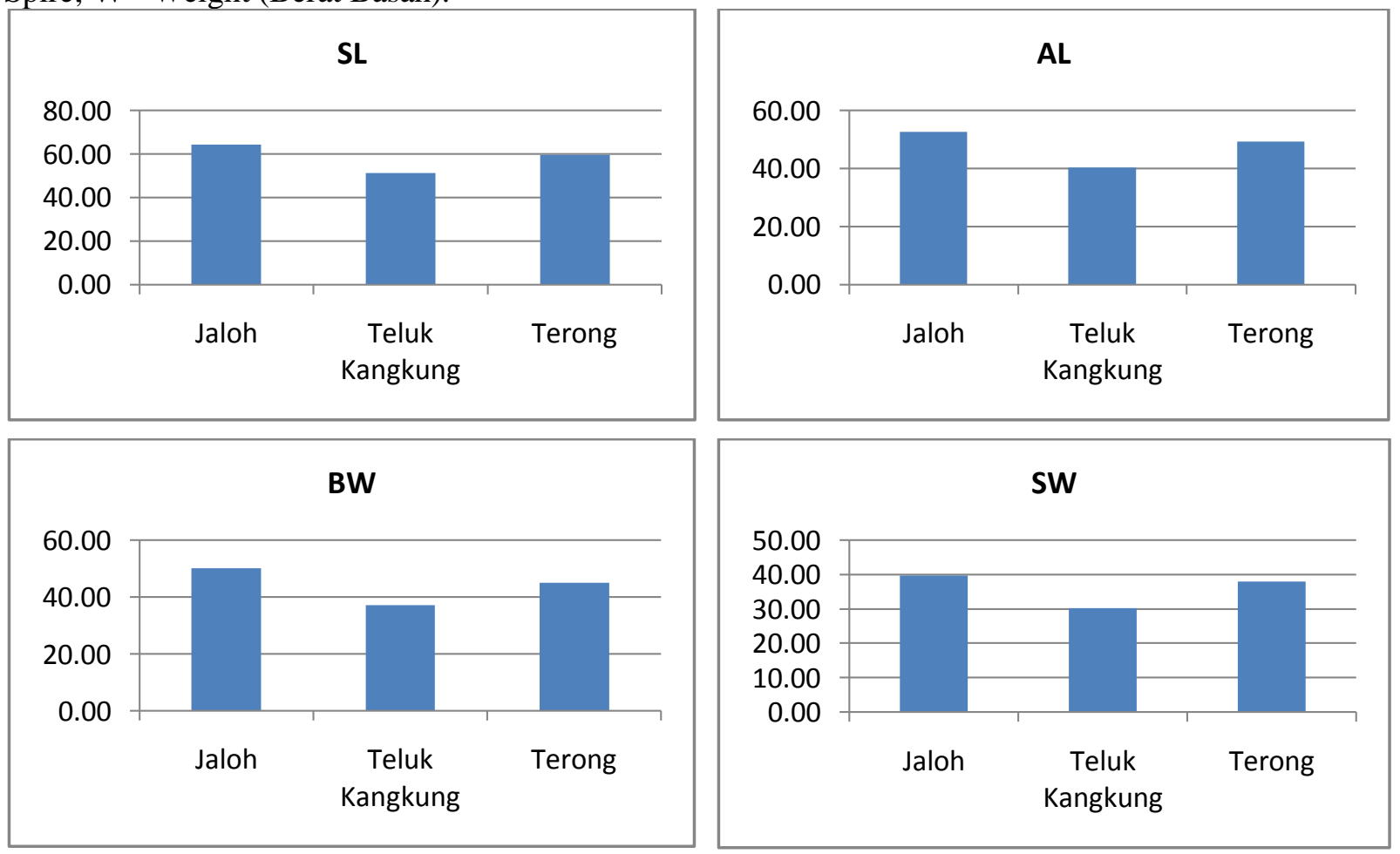

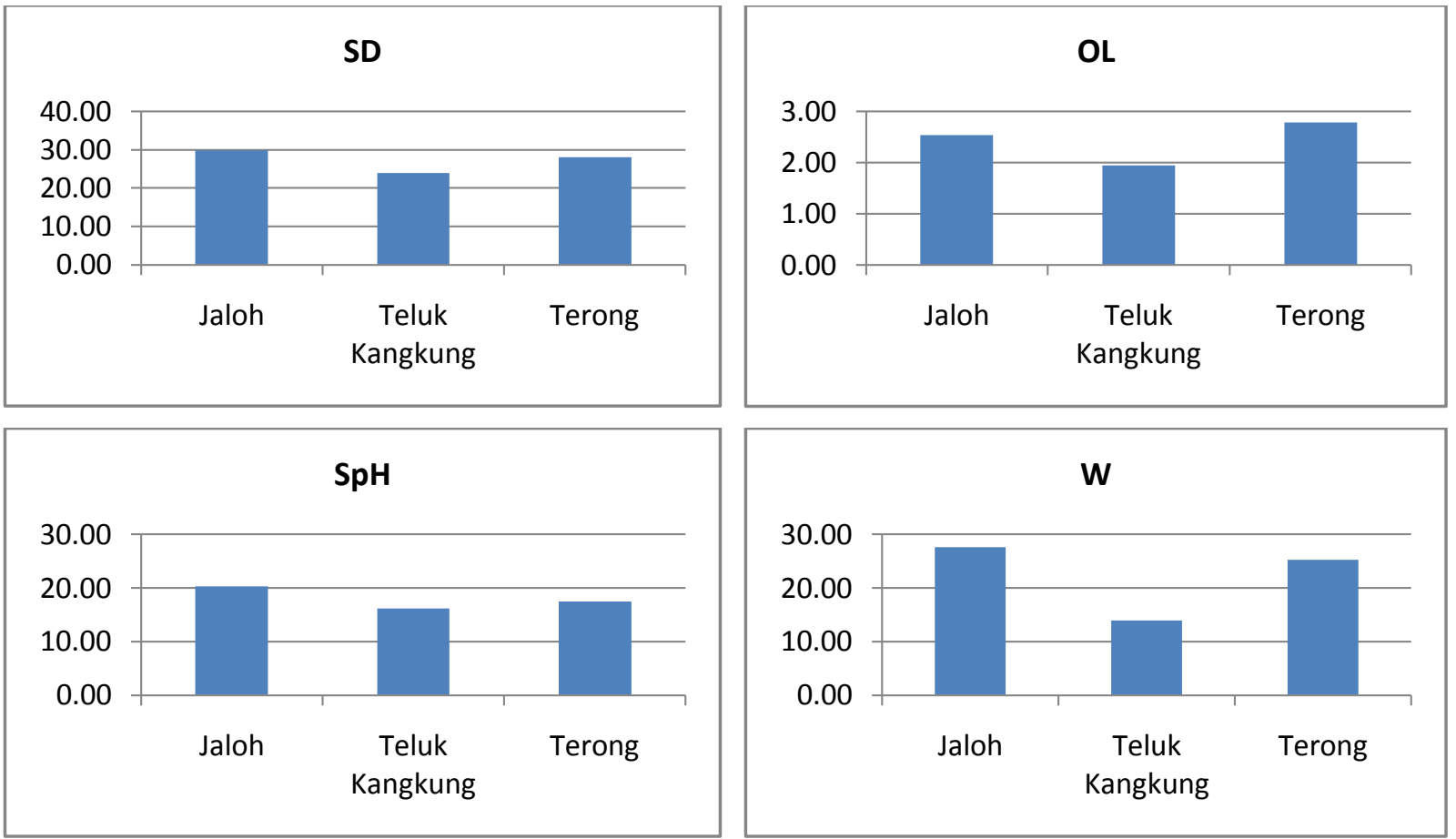

Gambar 2. Ukuran morfometrik Siput Gonggong S.canarium

Terdapat perbedan jumlah dan frekuensi panjang dan bobot Siput Gonggong berdasarkan jenis kelamin. Frekuensi panjang tertinggi Siput Gonggong di perairan Pulau Jaloh, pada ukuran 60.10-69.80mm sebanyak 140 individu. Sedangkan frekuensi yang terendah pada ukuran 48.35mm sebanyak 1 individu. Ukuran Siput Gonggong betina, frekuensi panjang tertinggi terdapat pada ukuran 60.10-69.80mm sebanyak 69 individu, sedangkan pada ukuran $48.35 \mathrm{~mm}$ memiliki frekuensi panjang terendah sebanyak 1 individu. Ukuran Siput Gonggong jantan, frekuensi panjang tertinggi terdapat pada ukuran 60.10$69.80 \mathrm{~mm}$ sebanyak 71 individu. Frekuensi bobot tertinggi pada berat 20.00-29.00 gr sebanyak 105 individu. Sedangkan frekuensi bobot terendah pada berat 51.00-54.00 gr sebanyak 4 individu.

Tabel 2. Frekuensi Panjang dan Berat S.canarium di Pulau Jaloh

\begin{tabular}{|c|c|c|c|c|c|c|c|}
\hline \multicolumn{4}{|c|}{ Frekuensi Panjang } & \multicolumn{4}{|c|}{ Frekuensi Berat } \\
\hline \multirow{2}{*}{ Selang Kelas } & \multicolumn{2}{|c|}{ Jenis Kelamin } & \multirow{2}{*}{ Jumlah } & \multirow{2}{*}{ Selang Kelas } & \multicolumn{2}{|c|}{ Jenis Kelamin } & \multirow{2}{*}{ Jumlah } \\
\hline & $\mathbf{M}$ & $\mathbf{F}$ & & & $\mathrm{M}$ & F & \\
\hline 48.35 & 0 & 1 & 1 & $10.00-19.00$ & 17 & 12 & 29 \\
\hline 51.39-59.98 & 30 & 14 & 44 & $20.00-29.00$ & 66 & 39 & 105 \\
\hline $60.10-69.80$ & 71 & 69 & 140 & $30.00-39.00$ & 21 & 41 & 62 \\
\hline \multirow[t]{2}{*}{$70.03-78.82$} & 5 & 25 & 30 & $40.00-47.00$ & 2 & 13 & 15 \\
\hline & & & & $51.00-54.00$ & 0 & 4 & 4 \\
\hline Jumlah & 106 & 109 & 215 & Jumlah & 106 & 109 & 215 \\
\hline
\end{tabular}


Frekuensi panjang tertinggi Siput Gonggong S.canarium di perairan Teluk Kangkung pada ukuran 50.50-59.95 mm sebanyak 47 individu. Sedangkan frekuensi yang terendah pada ukuran 14.4 dan $33.6 \mathrm{~mm}$ sebanyak 1 individu. Secara rinci dapat dilihat pada Tabel 3.

Tabel 3. Frekuensi Panjang dan Berat S.canarium di Teluk Kangkung.

\begin{tabular}{|c|c|c|c|c|c|c|c|}
\hline \multicolumn{4}{|c|}{ Frekuensi Panjang } & \multicolumn{4}{|c|}{ Frekuensi Berat } \\
\hline \multirow{2}{*}{ Selang Kelas } & \multicolumn{2}{|c|}{ Jenis Kelamin } & \multirow{2}{*}{ Jumlah } & \multirow{2}{*}{ Selang Kelas } & \multicolumn{2}{|c|}{ Jenis Kelamin } & \multirow{2}{*}{ Jumlah } \\
\hline & $\mathbf{M}$ & $\mathbf{F}$ & & & $\mathrm{M}$ & $\mathrm{F}$ & \\
\hline 14.4 & 0 & 1 & 1 & $3.00-9.00$ & 2 & 15 & 17 \\
\hline 33.6 & 1 & 0 & 1 & $10.00-19.00$ & 19 & 32 & 51 \\
\hline $40.50-49.95$ & 11 & 15 & 26 & $20.00-23.00$ & 0 & 10 & 10 \\
\hline $60.70-62.90$ & 1 & 2 & 3 & - & - & - & - \\
\hline Jumlah & 21 & 57 & 78 & Jumlah & 21 & 57 & 78 \\
\hline
\end{tabular}

Pada Pulau Terong, frekuensi panjang tertinggi Siput Gonggong pada ukuran 60.52$69.94 \mathrm{~mm}$ sebanyak 36 individu. Sedangkan frekuensi yang terendah pada ukuran $27.9 \mathrm{~mm}$ sebanyak 1 individu. Frekuensi panjang dan bobot berdasarkan jenis kelamin secara rinci dapat rilihat pada Tabel 4.

Tabel 4. Frekuensi Panjang dan Berat S.canarium di Pulau Terong

\begin{tabular}{|c|c|c|c|c|c|c|c|}
\hline \multicolumn{4}{|c|}{ Frekuensi Panjang } & \multicolumn{4}{|c|}{ Frekuensi Berat } \\
\hline \multirow{2}{*}{ Selang Kelas } & \multicolumn{2}{|c|}{ Jenis Kelamin } & \multirow{2}{*}{ Jumlah } & \multirow{2}{*}{ Selang Kelas } & \multicolumn{2}{|c|}{ Jenis Kelamin } & \multirow{2}{*}{ Jumlah } \\
\hline & $\mathbf{M}$ & $\mathbf{F}$ & & & $\mathbf{M}$ & $\mathbf{F}$ & \\
\hline 27.9 & 0 & 1 & 1 & $12.00-19.00$ & 13 & 4 & 17 \\
\hline $46.80-48.90$ & 5 & 1 & 6 & $20.00-29.00$ & 17 & 29 & 46 \\
\hline $51.00-59.70$ & 17 & 20 & 37 & $30.00-39.00$ & 4 & 15 & 19 \\
\hline $60.52-69.94$ & 12 & 24 & 36 & 47 & 1 & 0 & 1 \\
\hline $70.47-71.80$ & 1 & 3 & 4 & 54 & 0 & 1 & 1 \\
\hline Jumlah & 35 & 49 & 84 & Jumlah & 35 & 49 & 84 \\
\hline
\end{tabular}

Ukuran morfometrik yang diperloleh pada penelitian ini lebih tinggi dari ukuran morfomtrik yang pernah dilaporkan sebelumnya. BPP-PSPL-UNRI, (2010) melaporkan bahwa berat rata-rata Siput Gonggong 28,23 gr dengan kisaran berat antara 13,7-47,6 gr. Panjang siput gonggong berkisar antara 49 - $78 \mathrm{~mm}$ dengan rata-rata panjang 64,13 $\mathrm{mm}$. Ketebalan bibir luar (OL) yang ditemukan berkisar antara 1-6 mm dengan rata-rata 2,76 mm. Perbedaan sistematik luar antar individu yang berbeda jenis kelamin dalam spesies yang sama pada hewan Gonggong sangat jelas. Cob et al., (2008) melaporkan perbandingan antara jantan dan betina normal menunjukkan bahwa yang pertama memiliki cangkang yang jauh 
lebih besar, lebih berat, dan lebih memanjang daripada yang terakhir. Kerang jantan juga memiliki bibir yang secara signifikan lebih tebal dengan tingkat pelepasan bibir posterior dan lateral yang lebih tinggi.

Pengukuran morfometrik ketebalan bibir cangkang (OL) di masing-masing stasiun dapat menunjukan penentuan kedewasaan siput gonggong (BPP-PSPL-UNRI, 2010). Umumnya OL yang tipis menunjukkan Siput Gonggong masih muda. Hasil penelitian ini menunjukkan bahwa ukuran panjang yang dibawah $70 \mathrm{~mm}$ terdapat juga OL yang masih tipis (siput muda), dan ukuran panjang diatas $70 \mathrm{~mm}$ ada juga OL yang tebal. Pengukuran ketebalan OL pada masing-masing stasiun rata-rata sebesar 2.54 (Pulau Jaloh); 1.95 (Teluk Kangkung), dan 2.79 (Pulau Terong). Jika dilihat dari ketebalan OL Siput Gonggong S.canarium banyak ditemukan yang sudah dewasa di Pulau Terong jika dibandingkan di Pulau Jaloh dan Teluk Kangkung.

\section{Kepadatan dan Pola Sebaran}

Kepadatan merupakan jumlah individu yang tertangkap persatuan luas area pengambilan contoh. Kepadatan Siput Gonggong Strombus canarium di Pulau Jaloh memiliki kepadatan 3.58 ind $/ 60 \mathrm{~m}^{2}$ dengan jumlah (N) 215 individu, Teluk Kangkung memiliki kepadatan 1.3 ind $/ 60 \mathrm{~m}^{2}$ dengan $\mathrm{N}=78$ individu, dan Pulau Terong memiliki kepadatan 1.4 ind/60m 2 dengan $\mathrm{N}=84$ individu.

Kepadatan S.canarium yang terendah ditemui pada lokasi penelitian di Teluk Kangkung dan kepadatan tertinggi ditemui pada lokasi Pulau Jaloh dan Pulau Terong. Kepadatan yang tinggi hal ini diduga karena memilki substrat liat di Pulau Jaloh. Berdasarkan hasil pengukuran diketahui bahwa pola sebaran jenis Siput Gonggong jenis S.canarium di perairan Pulau Jaloh, Teluk Kangkung dan Pulau Terong memiliki pola sebaran jenis bersifat tidak acak dan mengelompok. Hal ini disebabkan sifat hidup Siput Gonggong yang berkoloni dan tidak tersebar luas di alam, sehingga suatu individu jenis hanya dapat ditemukan di tempat tertentu sesuai dengan preferensi habitatnya. Selain itu juga diduga berhubungan dengan tipe substrat pada daerah pengamatan yaitu liat, lempung berpasir dan pasir berlempung yang merupakan areal yang tenang dan terlindung dari gerakan arus yang kuat serta ketersediaan makanan yang ada di sekitar tempat hidupnya. Pola sebaran jenis ini mengindikasikan bahwa daerah pengamatan merupakan daerah yang potensial sebagai habitat Siput Gonggong. Hal ini didukung oleh beberapa faktor, diantaranya pola arus yang 
berkembang yang dapat menyebabkan terakumulasinya nutrien dan tersebarnya larva di areal tersebut, banyaknya gosong pasir yang membentuk daerah-daerah terlindung bagi Siput Gonggong serta relatif jauhnya dari lokasi pemukiman (Dody, 2007).

Tabel 5. Pola penyebaran Siput Gonggong S.canarium

\begin{tabular}{|c|c|c|c|c|c|c|c|}
\hline Lokasi & Id & $\mathbf{N}$ & $\mathbf{N}$ & $X^{2}$ & $X^{2}$ Hitung & $\begin{array}{c}X^{2}(0,05) \\
v=n-1(20-1)\end{array}$ & Pola Sebaran \\
\hline Jaloh & 6.77505 & 215 & 20 & 15801 & 1254.8605 & 30.14353 & Mengelompok \\
\hline Kangkung & 6.52015 & 78 & 20 & 2036 & 444.0513 & 30.14353 & Mengelompok \\
\hline Terong & 6.54618 & 84 & 20 & 2366 & 479.3333 & 30.14353 & Mengelompok \\
\hline Gabungan & 8.39184 & 377 & 60 & 20203 & 2838.3316 & 77.93052 & Mengelompok \\
\hline
\end{tabular}

Pola sebaran mengelompok ini juga berkaitan erat dengan hewan bentik untuk memilih daerah yang akan ditempatinya, khususnya substrat yang ada. Tipe substrat tertentu akan menarik atau menolak jenis hewan bentik untuk mendiami serta faktor-faktor fisik kimia yang berpengaruh pada kehidupan hewan bentik. Terdapatnya hewan bentik dewasa berarti daerah tersebut cocok untuk habitat hidup. Kemampuan hewan bentik memilih daerah untuk menetap serta kemampuannya untuk menunda metamorfosis membuat penyebarannya tidak acak (Nybakken,1988). Dilaporkan distribusi dan kelimpahan Siput Gonggong pada beberapa lokasi di perairan Lingga berkisar antara $0,2-1,9$ individu $/ \mathrm{m}^{2}$ atau rata-rata kelimpahan siput Gonggong berkisar antara 0,2-1,8 individu $/ \mathrm{m}^{2}$ dengan habitat lamun yang didominasi oleh Enhalus acoroides pada daerah pasang surut (BPP-PSPL-UNRI, 2010).

\section{Faktor Lingkungan}

\section{Kualitas Perairan}

Hasil pengukuran kualitas perairan di Pulau Jaloh tercatat $\mathrm{pH} 8.83$, suhu $25^{\circ} \mathrm{C}$, salinitas $30 \%$, DO $5.9 \mathrm{mg} / \mathrm{l}$, kecerahan $140 \mathrm{~cm}$, dan kecepatan arus $0.11 \mathrm{~m} /$ detik. Teluk Kangkung tercatat $\mathrm{pH} 8.76$, suhu $30.7^{\circ} \mathrm{C}$, salinitas $31^{\%}$ oo, DO $8.2 \mathrm{mg} / \mathrm{l}$, kecerahan $330 \mathrm{~cm}$, dan kecepatan arus $0.25 \mathrm{~m} /$ detik. Sedangkan Pulau Terong tercatat $\mathrm{pH} 8.76$, suhu $31.1^{\circ} \mathrm{C}$, salinitas 29\%, DO $8.3 \mathrm{mg} / \mathrm{l}$, kecerahan $300 \mathrm{~cm}$, dan kecepatan arus $0.25 \mathrm{~m} /$ detik. Kualitas perairan di masing-masing lokasi pengamatan masih dalam rentang baku mutu kualitas air untuk biota sesuai dengan Kepmen LH No. 51 Tahun 2004 untuk salinitas tidak disebutkan pada kisaran kondisi normal suatu lingkungan, bervariasi setiap saat (siang, malam dan musim), diperbolehkan terjadi perubahan sampai dengan $<5 \%$ salinitas rata-rata musiman. Baku mutu DO mengisyaratkan harus lebih besar dari $5 \mathrm{mg} / \mathrm{l}$. Berdasarkan bakumutu yang 
tertuang dalam Kepmen tersebut, maka nilai salinitas dan DO masih berada dalam kisaran ambang batas. Menurut Effendi (2003) bahwa sebagian besar biota akuatik sensitif terhadap perubahan $\mathrm{pH}$ dan menyukai nilai $\mathrm{pH}$ sekitar 7-8,5. Nilai $\mathrm{pH}$ akan mempengaruhi proses biologi kimiawi perairan. Keanekaragaman bentos mulai menurun pada $\mathrm{pH}$ 6-6,5. Sementara menurut Nybakken (1998) lingkungan perairan laut yang memiliki $\mathrm{pH}$ yang bersifat relatif lebih stabil dan berada dalam kisaran yang sempit, biasanya berkisar antara 7,5-8,4. Menurut Dody (2007) bahwa Siput Gonggong hidup pada kisaran pH antara 7,60-7,67.

Pada perairan laut yang masih alami, konsentrasi oksigen terlarut banyak dipengaruhi oleh aktivitas pengadukan dari adanya arus dan gelombang. Konsentrasi oksigen yang ditemukan pada daerah sampling tergolong baik untuk perkembangan organisme perairan (BPP-PSPL-UNRI, 2010). Menurut Dwiyitno, et al. (2018) melaporkan bahwa rendahnya DO dan tinggi BOD dan COD perairan merupakan indikator kontaminan biologis dan kimia yang sangat tinggi. Namun menurut Sutamihardja (1978) dalam Utami, 2012) kadar oksigen terlarut yang normal di perairan laut berkisar antara 5,7 - 8,5 mg/L.

Arus memiliki peran yang sangat penting dalam air, karena alirannya berpengaruh pada distribusi organisme, gas terlarut dan mineral yang terkandung di dalam air. Pada stasiun sampling kecepatan arus air laut selama pengambilan sampel mencapai $0,11-0,25 \mathrm{~m} /$ det. Kecepatan arus sangat bervariasi tergantung tempat yaitu terbuka ataupun tertutup, waktu seperti waktu pasang dan surut serta musim yaitu musim Utara, Selatan, Barat atau Timur. Saat musim tersebut, kecepatan arus dan arah arus dipengaruhi oleh massa air akibat dari arah angin. Aktivitas organisme perairan akan beradaptasi dengan berbagai fenomena alam tersebut, demikian juga aktivitas manusia yang melakukan penangkapan atau pengumpulan siput gonggong pada sekitar kawasan lokasi penelitian (BPP-PSPL-UNRI, 2010). Putra (2014) melaporkan bahwa kecepatan arus dengan kisaran 0,04-0,178 m/detik baik untuk kehidupan siput Gonggong.

\section{Substrat}

Keadaan substrat perairan pada daerah penelitian terdiri dari liat untuk di Pulau Jaloh, Lempung berpasir di Teluk Kangkung dan Pasir berlempung di Pulau Terong. Substrat dasar perairan merupakan parameter yang sangat penting bagi biota yang hidup di dasar perairan, khususnya siput gonggong sebagai habitat, tempat mencari makan, dan memijah atau bereproduksi. Hal ini disebabkan aktifitas siput gonggong banyak berhubungan dan dipengaruhi oleh kandungan dasar perairan (Utami, 2012). Menurut Dody (2007) bahwa 
spesies Siput Gonggong umumnya mendiami substrat lunak dan dapat ditemukan pada substrat yang didominasi oleh pasir hingga pasir berlumpur dan berada pada areal yang tenang dan terlindung dari gerakan arus yang kuat. Sementara menurut BPP-PSPL-UNRI (2010) jenis substrat pasir berlumpur memberikan habitat yang cocok untuk beberapa jenis kerang terutama dari jenis siput yaitu siput gonggong.

\section{Habitat Lamun}

Jenis Lamun pada tiga lokasi adalah Enhalus acoroides, Syringodium isoetifolium dan Halophila ovalis. Pada penelitian ini tidak ditemukan jenis lamun dalam plot pengamatan kecuali E. acoroides. Jenis S. isoetifolium dan H.ovalis dijumpai di luar plot pengamatan dalam jumlah yang sangat kecil, dari 600 sektor plot pengamatan vegetasi lamun di temukan sebanyak 1015 tegakan E. acoroides. Dilihat dari semua lokasi habitat laun di dominansi oleh lamun Enhalus acoroides.Dari ketiga lokasi penelitian ini yang dominan ditemukan jenis lamun E. acoroides.
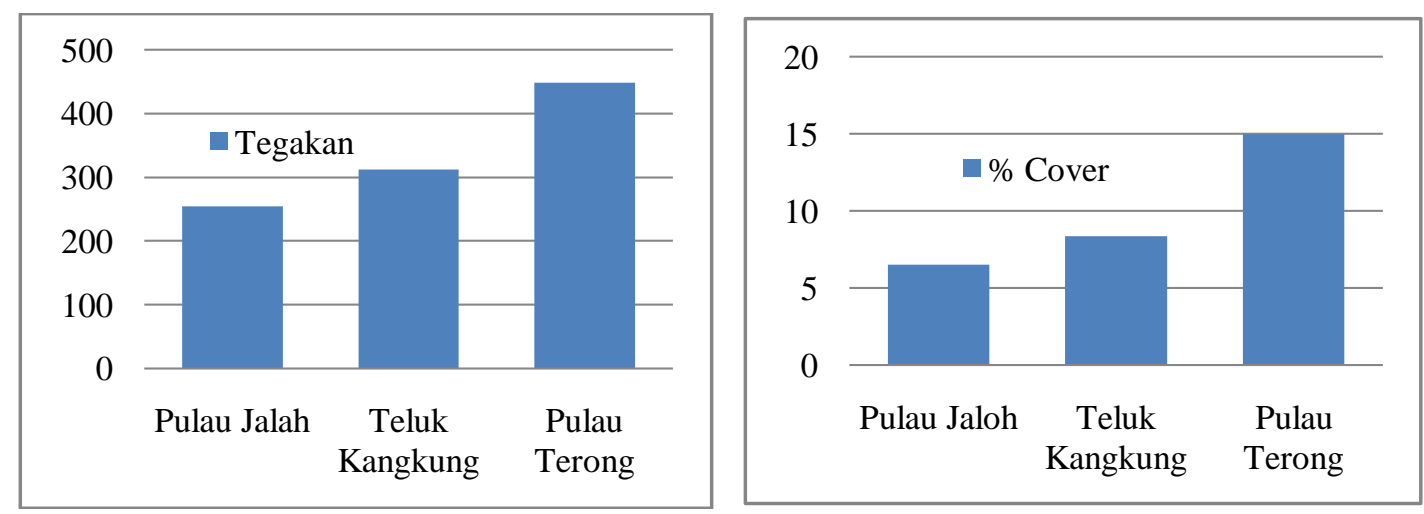

Gambar 3. Jumlah tegakan lamun dan persen tutupan lamun

Menurut Kiswara \& Hutomo (1985). E.acoroides tumbuh dengan baik pada substrat pasir berlumpur (pasir berlempung). Substrat perairan di Pulau Terong mendukung kehidupan E.acoroides. Substrat pasir dengan kandungan lumpur pada ekosistem padang lamun dalam jumlah tertentu merupakan habitat yang ideal bagi kehidupan siput gonggong, namun bila komposisi substrat didominasi oleh lumpur maka akan membahayakan kehidupan siput itu sendiri. Tingginya kandungan lumpur pada substrat dasar perairan akan menyebabkan makin meningkatnya partikel terlarut dan tersuspensi dalam kolom air. Hal ini akan berakibat pada rendahnya kadar oksigen dalam sedimen atau hipoksia (Borja et al., dalam Dody, 2007). Keberadaan lamun di habitat Siput Gonggong cukup penting karena menyangkut ketersediaan pasokan makanan yang berasal dari hancuran daun lamun (serasah) maupun sebagai tempat berlindung bagi anakan Siput Gonggong (Dody, 2011). 
Menurut Gosari \& Haris (2012) E.acoroides memiliki daun yang lebih tebal, lebar dan panjang, sehingga memiliki ruang fotosintesa yang lebih besar per individunya. Jenis ini memilki panjang daun hingga 1 meter. Sedangkan Menurut Lanuru (2011) yang melakukan transplantasi lamun jenis ini di Pulau Lae-lae dan Labbakkang mempunyai kemampuan bertahan hidup yang tinggi. Sementara menurut Feryatun et al., (2012) tingginya kerapatan jenis lamun di sebabkan karakteristik substrat, pertumbuhan lamun dan faktor lingkungan (kondisi lingkungan yang berbeda). Kerapatan jenis lamun dipengaruhi oleh faktor tempat tumbuh dari lamun tersebut diantaranya kedalaman, kekeruhan, tipe substrat, arus, dan suhu. Kerapatan lamun akan semakin tinggi jika kondisi lingkungan perairan tempat lamun tunbuh dalam keadaan baik (Daeng, 2018).

Penutupan lamun menggambarkan seberapa luas lamun menutupi suatu area dan biasanya dinyatakan dalam persen. Dari hasil analisa data tutupan lamun, di peroleh persen tutupan lamun pada tiga lokasi yaitu Pulau Jaloh sebesar 6.5\%, Teluk Kangkung sebesar 8,3\%, dan Pulau Terong sebesar 14,98\%. Menurut English et al., (1997) nilai persen tutupan lamun dari ketiga lokasi penelitian masih kategori rendah dengan skala 3 (1/8 to 1/4 dan 12.525\%). Menurut Wicaksono et al., (2012) penutupan lamun dipengaruhi oleh faktor lingkungan seperti jenis sedimen, kecepatan arus, dan suhu perairan. Kekeruhan dapat disebabkan oleh adanya partikel-partikel tersuspensi, baik oleh partikel-partikel hidup seperti plankton maupun partikel-partikel mati seperti bahan-bahan organik, sedimen dan sebagainya (Supriadi,2003). Sehubungan dengan habitat Siput Gonggong ini, Cob et al., (2012) berpendapat bahwa preferensi terhadap mikrohabitat tertentu dalam padang lamun berhubungan dengan makan, dan interaksi intra-spesifik di antara individu.

\section{KESIMPULAN}

Terdapat perbedaan morfometrik Siput Gonggong Strombus canarium di tiga lokasi. Pulau Jaloh memiliki nilai ukuran lebih tinggi dari lokasi lainnya pada semua indikator ukuran. Sedangkan di Teluk Kangkung merupakan yang paling kecil untuk semua indikator ukuran. Kepadatan siput Gonggong di Pulau Jaloh sebesar 3.58 individu/ 60m², Teluk Kangkung 1.3 individu $/ 60 \mathrm{~m}^{2}$, dan Pulau Terong sebesar 1.4 individu $/ 60 \mathrm{~m}^{2}$ dengan pola sebaran pada semua lokasi mengelompok. Kualitas perairan di masing-masing lokasi pengamatan masih dalam rentang baku mutu kualitas air untuk biota. Dari ketiga lokasi 
penelitian ini yang dominan ditemukan jenis lamun E.acoroides. Persentase tutupan lamun pada tiga lokasi yaitu Pulau Jaloh sebesar 6.5\%, Teluk Kangkung sebesar 8,3\%, dan Pulau Terong sebesar $14,98 \%$ masih dalam kategori rendah.

\section{UCAPAN TERIMA KASIH}

Ucapan terima kasih disampaikan kepada Kementerian Riset dan Pendidikan Tinggi (Ristekdikti) yang telah mendanai penelitian ini melalui Hibah PDP tahun 2018 dengan Kontrak 04/KP-PDP/LPPM/UNRIKA/IV/2018.

\section{REFERENSI}

BPP-PSPL-UNRI, 2010. Studi Distribusi Dan Eksploitas Siput Gonggong Di Lokasi Coremap II Kabupaten Lingga. Universitas Riau, Pekanbaru.

Cob, Z. C., Arshad, A., Bujang, J. S., Bakar, Y., Simon, K. D., \& Mazlan, A. G., 2012. Habitat preference and usage of Strombus canarium Linnaeus, 1758 Gastropoda: Strombidae) in Malaysian seagrass beds. Italian Journal of Zoology. Volume 79(3): 459-467.

Cob, Z. C., Arshad, A., Idris, M. H., Bujang, J. S., \& Ghaffar, M. A., 2008. Sexual Polymorphism in a Population of Strombus canarium Linnaeus, 1758 (Molusca: Gastropoda) at Merambong Shoal, Malaysia. Zoological Studies, Volume 47(3): 318-325.

Daeng, B., 2018. Keterkaitan Jenis dan Kerapatan Lamun dengan Tesktur di Dusun Biringkassi Desa Sapanang Kecamatan Binamu Kabupaten Jeneponto. Skripsi. Universitas Hasanuddin, Makassar.

Dody, S., 2007. Habitat dan sebaran spasial Siput Gonggong (Strombus turturella) di Teluk Klabat, Bangka Belitung. In Prosiding Seminar Nasional Moluska dalam Penelitian, Konservasi dan Ekonomi. Jakarta: Pusat Penelitian Oseanografi LIPI, p. 100.

Dody, S., 2011. Pola Sebaran, Kondisi Habitat dan Pemanfaatan Siput Gonggong (Strombus turturella) Di Kepulauan Bangka Belitung. Oseanologi dan Limnologi di Indonesia. Volume 37(2): 339-353.

Dwiyitno, Aji, N. \& Indriati, N., 2018. Heavy metal residue in fish and environmental quality of Barito River, South Kalimantan Province. Jurnal Pascapanen dan Bioteknologi Kelautan dan Prikanan. Volume 3(2): 147-155.

Effendi, H., 2003. Telaah kualitas air. Yogyakarta, Kanisius.

English, S., Wilkinson, C. \& Baker, Y., 1997. Survey Manual for Tropical Marine Resources (2nd Edition). Australian Institute of Marine Scienc, p.378. 
Feryatun, F., Hendrarto, B. \& Widyorini, N., 2012. Kerapatan dan distribusi lamun seagrass berdasarkan zona kegiatan yang berbeda di perairan pulau pramuka, kepulauan seribu. Journal of Management of Aquatic Resources. 1(1): 1-7.

Gosari, B.A.J. \& Haris, A., 2012. Studi Kerapatan dan Penutupan Jenis Lamun Di Kepulauan Spermonde. Torani (Jurnal Ilmu Kelautan dan Perikanan). Volume 22(3): 156-162.

Keputusan Menteri Negara Lingkungan Hidup Nomor 51 Tahun 2004 Tentang Baku Mutu Air Laut, Menteri Negara Lingkungan Hidup, Jakarta.

Khodijah \& Anggraini, S.F., 2015. Keberlanjutan Populasi Siput Gonggong (Strombus canarium). Jurnal Mitra Bahari. Volume 9(1): 37-42.

Kiswara, W. \& Hutomo, M., 1985. Habitat dan Sebaran Geografik Lamun. Oseana. Volume $\mathrm{X}(1): 21-30$.

Lanuru, M., 2011. Bottom Sediment Characteristics Affecting the Success of Seagrass (Enhalus acoroides) Transplantation in the Westcoast of South Sulawesi (Indonesia). International Conference on Chemical, Biological and Environmental Engineering, 20: 97-102.

Nybakken, J.W., 1988. Biologi Laut: Suatu Pendekatan Ekologis. M. Eidman et al., eds., PT Gramedia, Jakarta.

Putra, I.P., 2014. Kajian Kerapatan Lamun Terhadap Kepadatan Siput Gonggong (Strombus Canarium) Di Perairan Pulau Penyengat Kepulauan Riau. Skripsi. UMRAH, Tanjung Pinang.

Supriadi, 2003. Produktivitas Lamun Enhalus acoroides (LINN.F) Royle dan Thalassia hemprichii (EHRENB.) Ascherson di Pulau Barang Lompo Makassar. Skripsi. Institut Pertanian Bogor, Bogor.

Utami, D.K., 2012. Studi Bioekologi Habitat Siput Gonggong (Strombus turturella) Di Desa Bakit, Teluk Klabat, Kabupaten Bangka Barat, Provinsi Kepulauan Bangka Belitung. Skripsi. Institut Pertanian Bogor, Bogor.

Wicaksono, S.G., Widianingsih \& Hartati, S.T., 2012. Struktur vegetasi dan kerapatan jenis lamun di perairan kepulauan karimunjawa kabupaten jepara. Jurnal of Marine Research. Volume 1(2): 1-7. 